\title{
Progressive Muscle Relaxation Techniques effectiveness against The Difference of Fatigue Level of Patients Undergoing Hemodialysis in Medan
}

\author{
Cholina Trisa Siregar, Rizki Annisa Nasution \\ Department of Medical-Surgical Nursing, Faculty of Nursing, Universitas Sumatera Utara, Indonesia \\ siregar_cholina@yahoo.co.id
}

\begin{abstract}
Purpose. Chronic renal failure patients undergoing hemodialysis may experience symptoms such as fatigue. Symptoms of fatigue can cause patients unable to perform simple activities,can not remember things that have already passed, inability to socialize with other people and experiencing poor sleep quality.Methods. This study aims to determine differences in fatigue levels of hemodialysis patients after progressive muscle relaxation techniques. The design used in the study ispre test and post test without control group. Thesample of this study were 20 respondents.The sample in this study using purposive sampling.Analysis of the data used to determine the effectiveness of progressive muscle relaxation techniques was using Paired $t$-test. Results.The level of fatigue patients before given the action that is mild fatigue as much as 4 respondents (20\%), moderate as much as 6 respondents (30\%) and severe as much as 10 respondents (50\%). Fatigue levels after the patient given the action that is not fatigueas much as 4 respondents $(20 \%)$, mild as much as 6 respondents $(30 \%)$ and moderate as much as 10 respondents (50\%). There is significant difference between the mean fatigue level before and after given progressive muscle relaxation technique $(\mathrm{p}<0.000)$. Conclusion. Management corresponding to the problem of fatigue that occur in hemodialysis patients can improve the welfare and quality of life of patients.
\end{abstract}

Keywords - hemodialysis patient, the patient's fatigue level, progressive muscle relaxation techniques

\section{INTRODUCTION}

Chronic kidney disease (CKD) is a chronic disease that causes a decrease in kidney function permanently and require renal replacement therapy (Suwitra, 2006). Renal replacement therapy used is hemodialysis (Watnick\&Dirkx, 2013).

CKD patients undergoing hemodialysis in Indonesia in 2011 reached 15353 patients and in 2012 increased by 4268 patients (Indonesian Renal Registry, 2013). Medical record data in Rasyida Kidney and Hypertension Specialist Clinic Medan in 2013 showed that CKD patients undergoing hemodialysis as many as 310 patients.

CKD patients undergoing hemodialysis may experience symptoms such as fatigue, pruritus, constipation, anorexia, pain, sleep disorders, anxiety, dyspnea, nausea and depression (PERNEFRI, 2012; Murtagh et al., 2007).Figures patients who experience fatigue ranges from $60 \%$ to $97 \%$ in hemodialysis patients in the long term (Jhamb, Weisbord, Stell, Unruh, 2008). According to Kring\& Crane (2009) also suggested the prevalence of fatigue reaches $82 \%$ to $90 \%$ in patients with CKD undergoing hemodialysis in the long term.Fatigue experienced by patients with CKD undergoing hemodialysis give problems in patients. Horigan, Schneider, Docherty and Barrosoresearch results (2013) stated that fatigue can lead to CKD patients experienced dizziness after undergoing hemodialysis. Fatigue also causes patients unable to perform simple activities, can not remember things that have already passed, inability to socialize with other people and experiencing poor sleep quality.

Fatigue experienced in the long term lead to a result that is more burdensome and patients requiring treatment for a long time (Sulistini, Yetti, danHariyati, 2012). Koyama research results (2010) stated that fatigue in patients with CKD undergoing hemodialysis can lead to cardiovascular problems such as heart attack and stroke.These results are also supported by Sulistini, Yetti, and Hariyati research (2012) further suggests that the impact would have 
happened if fatigue does not get treatment in time will result in decreased quality of life and cardiovascular problems.

Handling can be done to reduce the fatigue experienced by patients with CKD undergoing hemodialysis is physical activity.It is supported by the results of Shapiro research (2008) suggested that CKD patients undergoing hemodialysis who work and had physical activity have lower levels of fatigue.According to Jhamb, et al (2009) also stated that by doing physical activity can reduce fatigue.

Based on the above researchers interested in studying about "Progressive Muscle Relaxation Technique Effectiveness against fatigue Levels in Patients with Chronic Kidney Disease Undergoing Hemodialysis".

\section{METHOD}

The design used in this study is quasiexperimental with pre-test and post test without control group.The population was all patients who undergo hemodialysis under one year, The number of patients in October 2015 was 150 people.Samples were selected using non probability sampling technique by purposive sampling with a sample size of 20 respondents.Sample inclusion criteria are: hemodialysis for less than 6 months, aged 20-60 years, undergoing hemodialysis 2 times per week.

The instrument used was a questionnaire on demographic data and the data of fatigue level.Fatigue level using Piper Fatigue Scale (PFS) questionnaires of Piper $\mathrm{BF}$ adopted from Danismaya (2008) that has been done 2 times a translation process that is English-Indonesian and Indonesian-English.PFS instrument has high validity value $r_{\text {count }}<r$ table from 0514 in the degree of freedom that is $\mathrm{N}-2=13$ (Danismaya, 2008).Reliability tests performed by using Cronbach Alpha on 10 respondents.Bivariate data analysis using Paired t-test with significance level $\alpha=0: 05$.

\section{RESEARCH RESULT}

Table 1 . The frequency and percentage distribution of demographic characteristic

\begin{tabular}{|c|c|c|}
\hline $\begin{array}{l}\text { Demographic } \\
\text { Data }\end{array}$ & $\begin{array}{l}\text { Frequency } \\
\text { (f) }\end{array}$ & $\begin{array}{l}\text { Percentage } \\
(\%)\end{array}$ \\
\hline \multicolumn{3}{|l|}{ Gender } \\
\hline Male & 10 & 50 \\
\hline Female & 10 & 50 \\
\hline \multicolumn{3}{|l|}{ Age } \\
\hline 21-30 years & 1 & 5 \\
\hline $31-40$ years & 3 & 15 \\
\hline $41-50$ years & 7 & 35 \\
\hline 51-60 years & 9 & 45 \\
\hline \multicolumn{3}{|l|}{ Marital status } \\
\hline Married & 19 & 95 \\
\hline Single & 1 & 5 \\
\hline \multicolumn{3}{|l|}{ Last education } \\
\hline Primary school & 2 & 10 \\
\hline $\begin{array}{l}\text { Junior high } \\
\text { school }\end{array}$ & 3 & 15 \\
\hline $\begin{array}{l}\text { Senior high } \\
\text { school }\end{array}$ & 10 & 50 \\
\hline Bachelor & 5 & 25 \\
\hline \multicolumn{3}{|l|}{ Occupation } \\
\hline $\begin{array}{l}\text { Government } \\
\text { employees }\end{array}$ & 2 & 10 \\
\hline Entrepreneur & 3 & 15 \\
\hline Housewife & 8 & 40 \\
\hline Does not work & 7 & 35 \\
\hline \multicolumn{3}{|l|}{$\begin{array}{l}\text { Period } \\
\text { undergoing } \\
\text { hemodialysis }\end{array}$} \\
\hline$<6$ months & 20 & 100 \\
\hline \multicolumn{3}{|l|}{$\begin{array}{l}\text { Frequency } \\
\text { Hemodialysis / } \\
\text { week }\end{array}$} \\
\hline 2x/ week & 20 & 100 \\
\hline \multicolumn{3}{|l|}{$\begin{array}{l}\text { Hemodialysis } \\
\text { Causes Disease }\end{array}$} \\
\hline $\begin{array}{l}\text { Chronic Kidney } \\
\text { Disease }\end{array}$ & 20 & 100 \\
\hline
\end{tabular}

The demographic data of respondents most respondents aged 51-60 years are as much as 9 respondents (30\%), last education senior high school as much as 10 respondents (50\%), mostly 
worked as a housewife as much as 8 respondents (40\%), period undergoing hemodialysis for less than 6 months as many as 20 respondents $(100 \%)$.

Table 2. Fatigue level before intervention( $n=20)$

\begin{tabular}{|c|c|c|c|}
\hline level & Fatigue & (f) & (\%) \\
\hline & Mild & 4 & 20 \\
\hline & Moderate & 6 & 30 \\
\hline & Severe & 10 & 50 \\
\hline
\end{tabular}

The above table illustrates the degree of fatigue in patients before the intervention gave the highest, severe fatigue level as many as 10 people (50\%)

Table 3. Fatigue level after intervention( $(n=20)$

\begin{tabular}{|c|c|c|}
\hline level Fatigue & (f) & (\%) \\
\hline fatigue $^{\text {Not }}$ & 4 & 20 \\
\hline Mild & 6 & 30 \\
\hline Moderate & 10 & 50 \\
\hline
\end{tabular}

The above table illustrates the degree of fatigue in patients after intervention gave the highest in moderate fatigue level were as many as 10 people $(50 \%)$

Table 4. Fatigue Level difference pretest and posttest $(n=20)$

\begin{tabular}{|c|c|c|c|}
\hline ses & ean & $\underset{\substack{\text { Sta } \\
\text { ndeviation }}}{\text { devion }}$ & $\underset{\text { tailed })}{\text { g. }(2-}$ \\
\hline $\begin{array}{ll} & P r \\
\text { etest } & \end{array}$ &, $15^{5}$ & $0^{2,3}$ & \\
\hline $\begin{array}{ll} & P o \\
\text { sttest } & \end{array}$ & ,85 & $5^{1.9}$ & \\
\hline & $\begin{array}{ll} & 2 \\
, 3 & \end{array}$ & & $000^{0,}$ \\
\hline
\end{tabular}

The above table shows that the average level of fatigue before the intervention given to the respondents is 5.15 with a standard deviation of 2.30 and 2.85 after the intervention given with a standard deviation of 1.95. Differences in the pretest and posttest mean among respondents was 2.3 with a $p$ value of 0.000 .It can be concluded that there is a significant difference between the mean fatigue level before and after the intervention is given.

\section{DISCUSSION}

Respondents in this study experienced varying levels of fatigue. Fatigue is a subjective feeling experienced by respondents can lead to decreased concentration, malaise, sleep disorders, emotional disorders, and decreased ability to perform daily activities. Respondents who experienced fatigue can cause feelings of distress so disturbed in their daily activities.Respondents also feel weak, tired, and dispirited. This is supported by Mollaoglu research (2009) stated that patients feel fatigue is a state of exhaustion and fatigue that ultimately led to a decrease in vitality and energy.Respondents usually rest or sleep when feeling tired, even respondents already know the limits of exhaustion so as to restrict the activities undertaken.

Respondents with fatigue also said they were not able to remember and concentrate. This is supported by Horigan, et al research (2013) stated that the respondents who undergo hemodialysis are not able to remember the names of people they have known for many years and things newly discussed.Other circumstances may interfere with the interaction of respondents with others.The consequences of fatigue experienced by patients undergoing hemodialysis is inhibiting socialization, feel isolated, lost time with family and difficulties in activities (Horigan, 2012). Further effects of fatigue can lead to decreased physical function and ability to perform activities of daily living, quality of life is poorer, and reduced survival (Bonner, Wellard, \&Caltabiano, 2010).The data was obtained by the pretest value ie 4 respondents (20\%) experienced no fatigue, 6 respondents $(30 \%)$ with mild fatigue and 10 respondents $(50 \%)$ with moderate fatigue. The intervention of progressive muscle relaxation techniques in 20 respondents have a positive impact after 1 month.This is evidenced by decrease in fatigue levels in all respondents with varying levels of fatigue. The difference of decreased in fatigue level caused by the condition of the patient, the frequency and persistence of respondents when performed the intervention of progressive muscle relaxation techniques. 
Respondents feel more relaxed and refreshed after given intervention of progressive muscle relaxation techniques. The patient's family also said they can help control the fatigue experienced by his/her family. Fatigue is felt no longer perceived as heavy as before given the intervention of progressive muscle relaxation techniques.

Respondents also reported feeling calm and can concentrate and can perform daily activities. This is supported by progressive muscle relaxation techniques can reduce muscle tension and make the body and mind feel calm and relaxed (Ari, 2010 in Dewi, S, Bayhakki and Misrawati, 2015). Respondents were no more likely to sleep to eliminate perceived fatigue, because they prefer to do progressive muscle relaxation techniques.

Differences in the pretest and posttest mean among respondents was 2.3 ,this means that there is a difference between the mean fatigue level before given intervention progressive muscle relaxation techniques with the fatigue level after given intervention progressive muscle relaxation techniques. This significant difference shows that progressive muscle relaxation techniques can be used as an alternative in patients who experience fatigue particularly patients undergoing hemodialysis.

The decrease in fatigue levels of the elderly after the progressive muscle relaxation techniques are supported by the theory that relaxation techniques that combined with controlled breathing exercises and a series of contractions and relaxation of muscle groups, stimulates the relaxation response both physical and psychological. Those responses because aroused of the parasympathetic autonomic nervous system activity of the raphe nuclei, located in the lower half of the pons and medulla resulting in a decrease in the body's metabolism, pulse, blood pressure, respiratory rate and increased secretion of serotonin (Guyton and Hall, 1997).

The difference in the fatigue level of pretestposttest is due to progressive muscle relaxation exercise is one easy and simple therapy that can increase the expression of negative feelings into positive. It is also evident during the intervention respondents felt goodtRF condition, calm and relaxed.

\section{CONCLUSIONS}

The fatigue level experienced by patients with renal failure undergoing hemodialysis therapy decreases with progressive muscle relaxation techniques, so as to improve the quality of life of patients. Recommended for nursing services in order to teach patients the progressive muscle relaxation techniques to reduce levels of fatigue experienced by patients.

\section{ACKNOWLEDGMENT}

Thanks to the respondents who are willing to become respondents in this study and thank to the nurses of hemodialysis to support during the data collection process.

\section{REFERENCES}

Danismaya, I. (2008). PengaruhTeknikRelaksasi Yoga terhadap Fatigue PenderitaKankerPascaKemoterapi di R.S. HasanSadikinBandung.Tesis.Universitas Indonesia

Horigan, A., Schneider, S., Docherty, S., \&Barroso, J., (2013). The Experience and SelfManagement of Fatigue in Hemodialysis Patients. 40, 113-123

Jhamb, M., Weisbord, S., Steel, J., \& Unruh, M., Fatigue in Patients Receiving Maintenance Dialysis: A Review of Definitions, Measures, and Contributing Factors, 52, 353-365

Sodikin, \&Suparti, S,. (2015). Fatigue PadaPasienGagalGinjal Terminal (GGT) yang MenjalaniHemodialisis RSUD Prof. DR. MargonoSoekardjoPurwokerto

Sulistini, R. (2010). GambaranFaktor yang Berhubungandengan Fatigue padaPasien yang MenjalaniHemodialisis di RSUP Dr. Moh.Hoesin Palembang. Tesis.Universitas Indonesia

Sulistini, R., Yetti, K., \&Hariyati, S., (2012). Faktorfaktor yang Mempengaruhi Fatigue padaPasien yang MenjalanoHemodialisis.JurnalKeperawatan Indonesia, 15, 75-82 
